\title{
Mere undervisning, større studieintensitet? En multilevelanalyse af 7.917 studerendes tidsforbrug
}

Kim Jesper Herrmann, cand.scient.pol., ph.d. og adjunkt ved Center for Undervisning og Læring, Aarhus Universitet.

Anna Bager-Elsborg, cand.scient.pol. og ph.d.-stipendiat ved Center for Undervisning og Læring, Aarhus Universitet.

Inger Borch Hansen, stud.scient.pol., studentermedhjælper, Center for Undervisning og Læring, Aarhus Universitet.

Rasmus Nielsen, stud.scient.pol., studentermedhjælper, Center for Undervisning og Læring, Aarhus Universitet.

\section{Reviewet artikel}

Der har de seneste år været betydelig interesse for danske universitetsstuderendes studieintensitet, og der er blevet givet forskellige anbefalinger $i$ forhold til, hoordan de studerende kan motiveres til at studere mere. Det empiriske grundlag for sådanne anbefalinger er imidlertid sparsomt. Formålet med dette studie er dels at beskrive den gennemsnitlige studieaktivitet blandt studerende på Aarhus Universitet, dels at analysere det indbyrdes forhold mellem undervisning og forberedelse. En multilevelanalyse af 7.917 studerendes selvrapporterede tidsforbrug viser overraskende en negativ sammenhæng mellem antallet af timer brugt på undervisning og antallet af timer brugt på forberedelse. Yderligere analyser tyder på, at sammenhængen mellem undervisningstid og forberedelsestid varierer på tværs af uddannelser.

\section{Indledning}

Danske universitetsstuderendes studieintensitet (forstået som den samlede tid brugt på undervisning og forberedelse) har været genstand for stigende opmærksomhed de senere år. Flere undersøgelser antyder, at studerende på danske videregående uddannelser i gennemsnit bruger mindre end 37 timer om ugen på deres studier (AU, 2011; Eurostudent, 2011; KU, 2013), og i en nylig udkommet rapport vurderer Kvalitetsudvalget (2014a), at danske studerendes studieindsats ligger $20 \%$ under den forventelige studieindsats beregnet ud fra ECTS-normen. Med henvisning til Trowler (2010) vurderer udvalget, at den lavere studieindsats repræsenterer et ikke indløst læringspotentiale (Kvalitetsudvalget, 2014a:50). Allerede i 2009 øgede regeringen STÅ-taksten for at tilskynde universiteterne til at øge udbuddet af undervisningstimer på humanistiske og samfundsvidenskabelige uddannelser, og effekten af dette 
tiltag er blevet evalueret af Rigsrevisionen (2012). Produktivitetskommissionen (2013) anbefaler på baggrund af data fra Eurostudent (2011), at antallet af undervisningstimer øges på studier med et i forvejen lavt timetal, og i udviklingskontrakten mellem Uddannelsesministeriet og de videregående uddannelser gældende for 20152017 er et af de fem centrale resultatmål netop at øge studieintensiteten (UFM, 2014). Tabel 1 viser en oversigt over de senere års undersøgelser af danske studerendes ugentlige tidsforbrug. Undersøgelser fra Københavns Universitet og Aarhus Universitet viser et gennemsnitligt tidsforbrug på cirka 28 timer/uge (AU, 2011; KU, 2013), Eurostudent (2011) viser et gennemsnit på cirka 33 timer mens Kvalitetsudvalget (2014a) har beregnet et gennemsnit på cirka 31 timer ugentligt fordelt på henholdsvis undervisning og forberedelse.

Tabel 1. Undersøgelser af studieaktivitet i timer/uge (bachelor/kandidat).

\begin{tabular}{|c|c|c|c|c|}
\hline & KU (2013) & AU (2011) & $\begin{array}{l}\text { Eurostudent } \\
\qquad(2011)^{a}\end{array}$ & $\begin{array}{l}\text { Kvalitetsudvalget } \\
(2014 \mathrm{a})^{\mathrm{b}}\end{array}$ \\
\hline Undervisning & $\begin{array}{c}12,7 \\
(13,5 / 11,4)\end{array}$ & $\begin{array}{c}12,0 \\
(12,9 / 9,8)\end{array}$ & $\begin{array}{c}13,7 \\
(15,9 / 11,7)\end{array}$ & $\begin{array}{l}13,2 \\
(-/-)\end{array}$ \\
\hline Forberedelse & $\begin{array}{c}14,9 \\
(15,3 / 14,2)\end{array}$ & $\begin{array}{c}16,3 \\
(16,5 / 16,8)\end{array}$ & $\begin{array}{c}19,7 \\
(18,3 / 21,1)\end{array}$ & $\begin{array}{l}17,4 \\
(-/-)\end{array}$ \\
\hline Erhvervsarbejde & $\begin{array}{c}7,5 \\
(6,5 / 9,1)\end{array}$ & $\begin{array}{c}7,0 \\
(5,7 / 9,3)\end{array}$ & $\begin{array}{c}7,7 \\
(6,6 / 8,7)\end{array}$ & $\begin{array}{l}8,9 \\
(-/-)\end{array}$ \\
\hline Studieuge & 27,6 & 28,3 & 33,4 & 30,6 \\
\hline$N$ & 11.323 & 8.527 & 2.189 & 4.087 \\
\hline Svarprocent & $28 \%$ & $37 \%$ & $26 \%$ & $21 \%$ \\
\hline Sample & $\begin{array}{c}\text { Studerende på } \\
\text { KU }\end{array}$ & $\begin{array}{c}\text { Studerende på } \\
\text { AU }\end{array}$ & $\begin{array}{l}\text { Tilfældigt udvalgt } \\
\text { stikprøve }\end{array}$ & $\begin{array}{l}\text { Stratificeret } \\
\text { stikprøve }\end{array}$ \\
\hline
\end{tabular}

Note: Beregningerne bygger på universitetsstuderendes selvrapporterede tidsforbrug i en uge med undervisning. Bemærk, at der forekommer nuancer i den måde, hvorpå de studerende er spurgt.

Kilder: AU (2011), Eurostudent (2011), KU (2013), Kvalitetsudvalget (2014a).

a) Forfatternes egne beregninger på baggrund af tal for danske universitetsstuderende, som venligst er udlånt af Universitets- og Bygningsstyrelse. Af hensyn til sammenlignelighed har vi ekskluderet professionsbachelorer og andre videregående uddannelser.

b) Ingen data tilgængelige, der tillader opdeling i bachelor og kandidat.

Undersøgelserne har desuden samstemmende vist, at studerende inden for natur- og sundhedsvidenskabelige uddannelser ('våde' fagområder) har længere studieuger end studerende på humanistiske og samfundsvidenskabelige uddannelser ('tørre' fagområder). Forskellen i studieintensiteten imellem de 'tørre' og 'våde' fagområder er af Eurostudent (2011), Produktivitetskommissionen (2013) og Kvalitetsudvalget (2014) blevet tolket som et udslag af, at der på sidstnævnte 'tørre' fagområder generelt er væsentligt færre undervisningstimer. Kun to studier har imidlertid undersøgt korrelationen mellem timer brugt på undervisning og timer brugt på forberedelse. På baggrund af en rundspørge blandt 707 studerende, der var tilmeldt et kommercielt 
webpanel, fandt tænketanken DEA (2013) en negativ korrelation mellem antal timers undervisning og antal timers forberedelse kontrolleret for effekterne af køn, alder, fakultet og motivation for studievalg. Resultatet bør dog tolkes yderst varsomt, da der er knyttet store metodiske usikkerheder til studiet grundet selvselektion (deltagerne har selv skullet tilmelde sig et panel, og dermed er en vigtig forudsætning for at generalisere resultaterne brudt). Kvalitetsudvalget (2014a) undersøgte sammenhængen mellem tidsforbrug på den ene side og otte såkaldte læringsindikatorer på den anden. Selv om rapportens fokus således ikke var relationen mellem undervisnings- og forberedelsestimer, fremgår det af bilagsmaterialet, at der var en meget svag men statistisk signifikant og positiv sammenhæng mellem antallet af undervisningstimer og antallet af forberedelsestimer kontrolleret for effekterne af alder, køn, hovedområde, karaktergennemsnit og ECTS-point (Kvalitetsudvalget, 2014b:21).

\section{Samspillet mellem undervisning og forberedelse}

I de seneste årtier har man kunnet iagttage en gradvis udvikling i den måde, hvorpå undervisning begrebsliggøres og praktiseres (Baeten et al., 2010). En hyppigt forekommende opfattelse af undervisning som transmission af viden fra underviser til studerende er blevet udfordret, og dermed er også den forelæsningsdominerede praksis i form af passiv 'stofgennemgang' i stigende grad blevet udfordret. Som alternativt til det transmissions- og underviserrettede paradigme kan man tale om et 'studenterrettet' paradigme, hvor udgangspunktet for tilrettelæggelse af undervisning er studerendes læring og læringsaktiviteter. Også inden for dansk universitetspædagogisk litteratur er der i meget højere grad fokus på undervisningsformer, der favoriserer studenterinddragelse og feedback end på undervisningsformer, der favoriserer formidling og stofgennemgang (se fx Rienecker et al., 2013 eller Ulriksen, 2014). Dette paradigmeskifte hviler blandt andet på en læringsteoretisk antagelse om, at læring - i sidste ende - kun kan ske gennem de studerendes egne læringsaktiviteter (Biggs, 2012) samt på empirisk forskning, der viser, at det, der kendetegner dygtige undervisere, er, hvad underviserne formår at motivere de studerende til at gøre, ikke hvad underviseren i sig selv gør (Hattie, 2009). Ifølge moderne universitetspædagogisk tænkning er undervisning og forberedelse således ikke substitutter men komplementære: Undervisning tilskynder ideelt set studerende til at indgå i et selvstændigt læringsarbejde før, under og efter undervisningen. Særligt på universitet, hvor antallet af konfrontationstimer er lille i forhold til gymnasieskolen og andre professionsrettede uddannelser, er læringsudbyttet stærkt afhængig af læringsarbejdet mellem timerne. Også udbyttet af selve undervisningen er i høj grad betinget af, hvor meget og hvordan de studerende har arbejdet forud for undervisningen. 


\section{Artiklens formål}

De ovennævnte undersøgelser til trods hersker der stadig usikkerhed om omfanget af danske studerendes studieintensitet, og særligt hersker der usikkerhed om det relative forhold mellem undervisning og forberedelse. Med andre ord er der ikke for nuværende empirisk støtte for en antagelse om, at en investering i flere undervisningstimer med sandsynlighed vil lede til større studieintensitet. Formålet med dette studie er at beskrive universitetsstuderendes studieintensitet forstået som den tid, studerende ugentligt bruger på studierelaterede aktiviteter, og dernæst at undersøge forholdet mellem undervisning og forberedelse. Vi stiller følgende spørgsmål:

1) Hvor meget tid bruger studerende på Aarhus Universitet på henholdsvis undervisning og forberedelse?

2) Hvad er den indbyrdes sammenhæng mellem tid brugt på undervisning og tid brugt på forberedelse?

\section{Metode}

\section{Dataindsamling}

Data blev indsamlet i foråret 2014 som led i Aarhus Universitets studiemiljøundersøgelse. Et link til et elektronisk spørgeskemaet blev sendt ud til 34.510 studerende midt i semesteret, og med en svarprocent på 40 endte vi med 13.647 gyldige besvarelser. Alle studerende var indskrevet på fuldtidsnormerede uddannelser.

At måle tidsforbrug er forbundet med store udfordringer, særligt overrapportering (Rockwool Fondens Forskningsenhed, 2013). For at imødegå disse målingsproblemer bad vi de studerende tage udgangspunkt i den netop forgangne uge, ligesom vi for hver tidskategori definerede kategorien. Følgende instruktion var at finde i spørgeskemaet: "Tænk tilbage på de sidste syv dage. Hvor mange timer har du brugt på følgende aktiviteter?" Forberedelse blev defineret som "læsning, læsegruppearbejde, skrivning, eksamenstilmelding, skaffe litteratur, skrive mails og lignende organisering af studiehverdagen", og undervisning blev defineret som "forelæsninger, holdtimer, øvelsestimer og lignende." Kategorien erhvervsarbejde er en sammenlægning af kategorierne "studierelevant erhvervsarbejde" og "ikke-studierelevant erhvervsarbejde". En sådan kategorisering er nødvendig men er samtidig uundgåeligt forbundet med en vis usikkerhed, og da undervisning organiseres og ikke mindst omtales forskelligt, kan der forekomme et overlap. Fx praktiserer man på nogle universitetsuddannelser lektiecafelignende arrangementer, hvor studerende forbereder sig selvstændigt, mens en underviser er til stede i lokalet. 


\section{Datagrundlag}

For at kunne sammenligne resultaterne af dette studie med tidligere studier valgte vi kun at inkludere studerende på bachelor- og kandidatuddannelser, hvilket betød udelukkelse af professionsbachelor- og diplomingeniørstuderende. Vi valgte også at udelukke specialestuderende, og ydermere valgte vi kun at inkludere studerende, som i spørgeskemaet havde oplyst, at de i det pågældende semester rent faktisk fulgte fag af et samlet omfang på 30 ECTS. Det vil sige, at undersøgelsen fokuserede på studerende som både formelt og reelt deltog i undervisning svarende til fuldtidsnormering.

For at undgå en skævvridning af resultaterne på grund af ekstreme værdier valgte vi at definere en variationsbredde for, hvad vi vurderede var plausible værdier for en samlet studieuge. Dette betød i praksis, at studerende med en studieuge på 0 timer eller en studieuge over 84 timer (svarende til 12 timers effektive studier pr dag) blev ekskluderet af analysen. Yderligere analyser af uni- og multivariate ekstreme observationer afslørede ikke observationer, som gav anledning til bekymring for skævvridning af resultaterne. Det endelig datasæt bestod af 7.917 studerende i alderen 18 til 69 år $(\mathrm{M}=23,7 ; \mathrm{SD}=4,0)$, hvoraf 40\% var mænd og 60\% kvinder. De studerende kom fra humaniora (32\%), samfundsvidenskaberne (36\%), sundhedsvidenskab (16\%) og naturvidenskab (17\%). $71 \%$ var bachelorstuderende og $29 \%$ kandidatstuderende. $6 \%$ havde udenlandsk statsborgerskab.

\section{Statistiske analyser}

Almindelig lineær regression bygger på antagelsen om, at observationerne i datasættet er uafhængige af hinanden (fravær af autokorrelation), men studerende vil typisk være del af et hold, som er del af en årgang, som er del af en uddannelse osv. Inden for samme uddannelse vil de studerende blive præget af fælles normer og oplevelser, og dette er medvirkende til at variationen mellem studerende inden for en uddannelse vil være mindre end variationen mellem de studerende overordnet betragtet (autokorrelation). Multilevelmodeller tager højde for at observationerne i data er indlejret i hierarkier. Resultatet er mere præcise estimater, mere præcise standardfejl og dermed mindre risiko for Type 1-fejl. Desuden tillader multilevelmodeller skæringspunkter og hældningskoefficienter at variere inden for grupper på højere niveauer (Tabachnick \& Fidell, 2007). Som foreslået af Hox (2012) valgte vi en strategi, hvor den statistiske model udbygges gradvist. Vi udførte almindelige forudsætningstest for multipel lineær regression (Tabachnick \& Fidell, 2007) samt en Hausman-test for at bekræfte at en random effects-model var hensigtsmæssig (RabeHesketh \& Skrondal, 2008:122). Alle analyser blev foretaget i STATA 13. 


\section{Analyse}

\section{Gennemsnitlig studieintensitet}

Det første skridt i analysen var at udregne de studerendes studieintensitet, og resultaterne er vist i tabel 2. De studerende brugte ifølge egen vurdering 13,1 timer på undervisning, 17,2 timer på forberedelse, og 6,2 timer på erhvervsarbejde (heraf 2,9 timer på studierelevant erhvervsarbejde). Dette gav en gennemsnitlig studieuge på 30,3 timer.

Tabel 2. Studerende gennemsnitlige tidsforbrug i timer pr. uge (standardafvigelser i parentes)

\begin{tabular}{lccc|cc} 
& Alle & $\begin{array}{c}\text { Humanistiske } \\
\text { udd. }\end{array}$ & $\begin{array}{c}\text { Samfundsv. } \\
\text { udd. }\end{array}$ & $\begin{array}{c}\text { Sundhedsv. } \\
\text { udd. }\end{array}$ & Naturv. udd. \\
Undervisning & 13,1 & 9,8 & 11,9 & 16,8 & 18,5 \\
& $(7,2)$ & $(4,3)$ & $(6,2)$ & $(8,9)$ & $(7,3)$ \\
Forberedelse & 17,2 & 16,5 & 17,9 & 16,9 & 17,6 \\
& $(10,3)$ & $(9,6)$ & $(10,7)$ & $(10,3)$ & $(10,6)$ \\
Arbejde & 6,2 & 6,5 & 7,7 & 4,7 & 3,8 \\
& $(7,7)$ & $(7,9)$ & $(8,0)$ & $(7,0)$ & $(6,1)$ \\
Studieuge [underv.+ & $\mathbf{3 0 , 3}$ & $\mathbf{2 6 , 3}$ & $\mathbf{2 9 , 8}$ & $\mathbf{3 3 , 7}$ & $\mathbf{3 6 , 2}$ \\
forb.] & $(11,7)$ & $(10,2)$ & $(11,2)$ & $(12,5)$ & $(11,5)$ \\
\hline N & 7.917 & 2.512 & 2.858 & 1.319 & 1.228 \\
\hline
\end{tabular}

Note: Studerende som i spørgeskemaet har angivet, at de i pågældende semester følger fag af et omfang på 30 ECTS-point.

Som det imidlertid også ses af de rapporterede standardafvigelser i tabel 2 er der en betydelig spredning de studerende imellem, hvad angår studieintensiteten, og nedenstående figur 1 illustrerer denne spredning. 
Figur 1. Spredning i ugentlig studieaktivitet (undervisning + forberedelse) på tværs af fakulteter

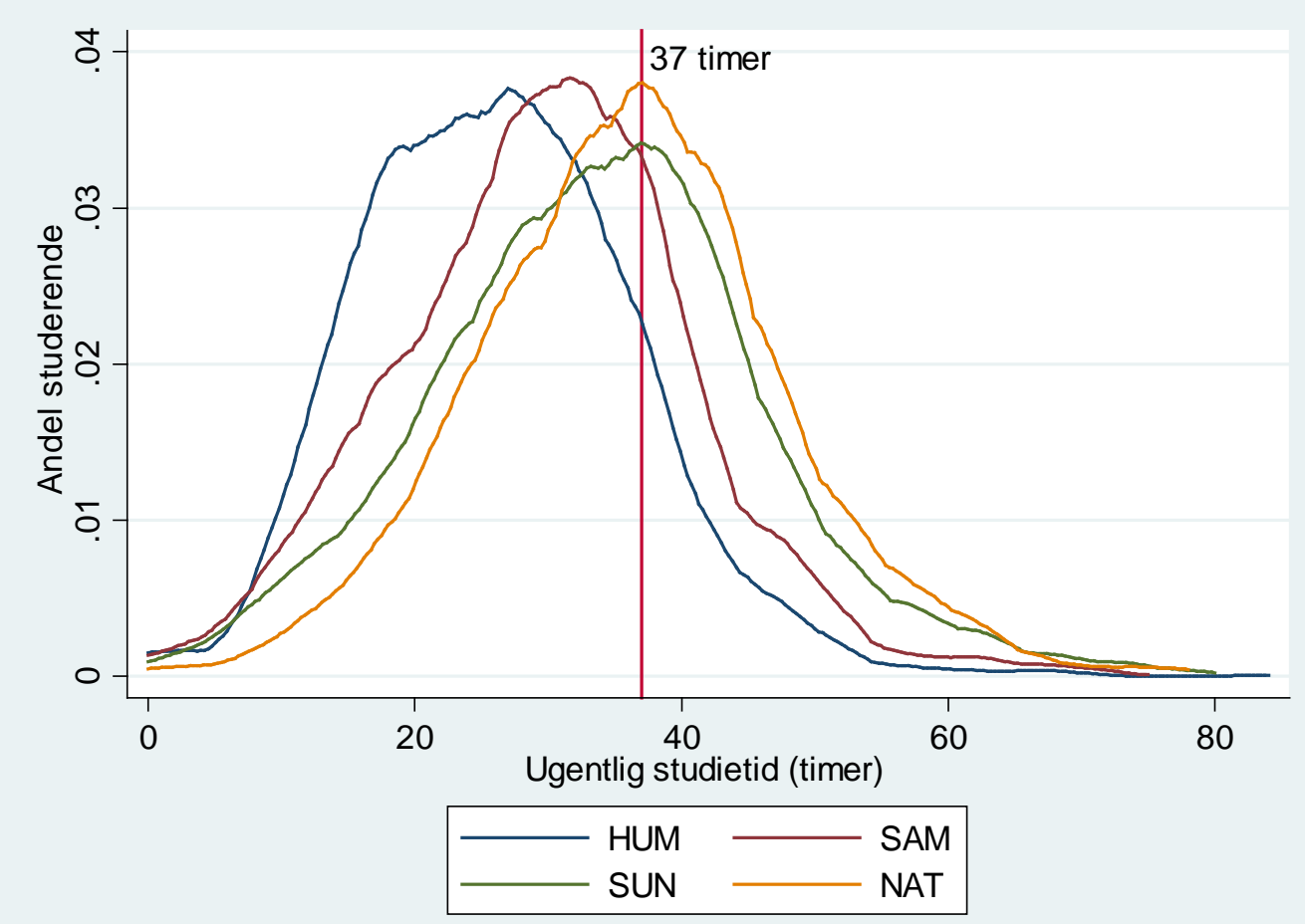

Note: HUM (humanistiske uddannelser), SAM (samfundsvidenskabelige og merkantile uddannelser), SUN (sundhedsvidenskabelige uddannelser), NAT (naturvidenskabelige uddannelser).

Af tabel 2 kan vi også observere øjensynlige forskelle mellem de enkelte fagområder, fx indikerer svar fra de studerende på natur- og sundhedsvidenskabelige uddannelser, at de bruger mere tid på undervisningsaktiviteter end studerende på humanistiske og samfundsvidenskabelige uddannelser, mens svar fra studerende på humanistiske og samfundsvidenskabelige uddannelser indikerer, at der her bruges mere tid på erhvervsarbejde. En variansanalyse bekræfter, at der er systematiske forskelle de fire fagområder imellem hvad angår de studerendes angivelse af tid brugt på henholdsvis undervisning $\left(F[3,7.916]=686,73, p<0,001, \eta_{p^{2}}=0,206\right)$, forberedelse $(F[3$, $\left.7.916]=9,23, p<0,001, \eta_{p}{ }^{2}=0,004\right)$ og erhvervsarbejde $(F[3,7.916]=101,57, p<0,001$, $\left.\eta_{\mathrm{p}}{ }^{2}=0,037\right)$.

\section{Forberedelse og undervisning}

I den næste del af analysen undersøger vi ved hjælp af multilevelanalyse, hvordan de studerendes rapporterede tid brugt på ugentlige forberedelse korrelerer med den tid, de angiver at bruge på undervisning og erhvervsarbejde kontrolleret for variablene køn, alder, studietrin og læsegruppemedlemskab. Det laveste niveau i den hierarkiske model er de enkelte studerende ( $\mathrm{N}=7.856)$, og uddannelsen udgør gruppevariablen på det øvre niveau $(\mathrm{N}=99)$. Resultaterne er vist $\mathrm{i}$ tabel 3. 
Tabel 3. Multilevel-model for sammenhængen mellem timers forberedelse (afhængig variabel) og timers undervisning.

\begin{tabular}{|c|c|c|c|c|}
\hline & Model 0 & Model 1 & Model 2 & Model 3 \\
\hline & $\begin{array}{l}\text { Kun grup- } \\
\text { pevar. }\end{array}$ & $\begin{array}{l}\text { Model } 0+\text { variabel } \\
\text { skæringspunkt }\end{array}$ & $\begin{array}{l}\text { Model } 1+\text { kon- } \\
\text { trolvariable }\end{array}$ & $\begin{array}{l}\text { Model } 2+\text { varia- } \\
\text { bel effekt af } \\
\text { undervisning }\end{array}$ \\
\hline Konstant & $\begin{array}{c}16,90 * * * \\
(0,34)\end{array}$ & $\begin{array}{c}21,33^{* * *} \\
(0,42)\end{array}$ & $\begin{array}{c}13,87^{* * *} \\
(0,93)\end{array}$ & $\begin{array}{c}13,70 * * * \\
(1,00)\end{array}$ \\
\hline Undervisning (timer/uge) & & $\begin{array}{c}-0,25 * * * \\
(0,02)\end{array}$ & $\begin{array}{c}-0,25 * * * \\
(0,02)\end{array}$ & $\begin{array}{c}-0,23 * * * \\
(0,03)\end{array}$ \\
\hline Arbejde (timer/uge) & & $\begin{array}{c}-0,20 * * * \\
(0,01)\end{array}$ & $\begin{array}{c}-0,20 * * * \\
(0,01)\end{array}$ & $\begin{array}{c}-0,13 * * * \\
(0,01)\end{array}$ \\
\hline Alder (år) & & & $\begin{array}{c}0,25 * * * \\
(0,03)\end{array}$ & $\begin{array}{c}0,25 * * * \\
(0,03)\end{array}$ \\
\hline Kvinde (mand, reference) & & & $\begin{array}{c}1,95^{* * *} \\
(0,24)\end{array}$ & $\begin{array}{c}1,94 * * * \\
(0,24)\end{array}$ \\
\hline Kandidat (bachelor, reference) & & & $\begin{array}{c}-1,14^{* * *} \\
(0,32)\end{array}$ & $\begin{array}{c}-1,09 * * * \\
(0,32)\end{array}$ \\
\hline $\begin{array}{l}\text { Har læsegruppe (ikke medlem, } \\
\text { reference) }\end{array}$ & & & $\begin{array}{c}1,15^{* * *} \\
(0,24)\end{array}$ & $\begin{array}{c}1,19 * * * \\
(0,24)\end{array}$ \\
\hline$\sigma^{2}$ (uddannelse) & $\begin{array}{l}8,29 * \\
(1,54)\end{array}$ & $\begin{array}{l}7,86^{*} \\
(1,48)\end{array}$ & $\begin{array}{l}8,94^{*} \\
(1,66)\end{array}$ & $\begin{array}{l}15,25^{*} \\
(3,91)\end{array}$ \\
\hline$\sigma^{2}$ (studerende) & $\begin{array}{r}97,75^{*} \\
(1,59)\end{array}$ & $\begin{array}{c}93,95 * \\
(1,51)\end{array}$ & $\begin{array}{r}92,15^{*} \\
(1,50)\end{array}$ & $\begin{array}{l}91,30^{*} \\
(1,47)\end{array}$ \\
\hline$\sigma^{2}$ (hældning undervisning) & & & & $\begin{array}{l}0,03^{*} \\
(0,01)\end{array}$ \\
\hline cov (forberedelse; undervisning) & & & & $\begin{array}{l}-0,44^{*} \\
(0,20)\end{array}$ \\
\hline Log likelihood & $-29.226,34$ & $-29.070,14$ & $-28.999,97$ & $-28.985,86$ \\
\hline $\mathrm{N}_{\text {uddannelser }}$ & 99 & & & \\
\hline $\mathrm{N}_{\text {studerende }}$ & 7.856 & & & \\
\hline
\end{tabular}

Note: Timers forberedelse pr uge er afhængig variabel.

Note: ${ }^{*} \mathrm{p}<0,05 ; * * \mathrm{p}<0,01 ; * * * \mathrm{p}<0,001$. Standardfejl i parentes.

Model 0 viser, at den del af variansen i forberedelse, som kan tilskrives uddannelsesniveauet $(8,29 /[8,29+97,75])$ udgør 7,8 procent. En supplerende variansanalyse viser, at der er statistisk signifikante forskelle mellem uddannelserne, hvad angår forberedelse $(F[98,7.900]=7,60, p<0,001)$. Således viser det sig hensigtsmæssigt at fortsætte analysen i form af multivel-analyse.

I model 1 har vi inkluderet undervisningsaktivitet og erhvervsarbejde som forklarende variable. Analysen viser her en statistisk signifikant, negativ sammenhæng mellem forberedelse og henholdsvis undervisning og erhvervsarbejde. 
Model 2 inkluderer kontrolvariablene alder, køn, studietrin og læsegruppemedlemskab. Vi finder en statistisk signifikant korrelation mellem samtlige fire kontrolvariabel og forberedelse. Sammenhængene mellem forberedelse og henholdsvis undervisning og erhvervsarbejde forbliver uændrede ved inklusion af kontrolvariable i modellen.

Model 3 er en gentagelse af model 2 med den tilføjelse, at vi tillader korrelationskoefficienten for undervisning at variere på tværs af uddannelserne. Med andre ord undersøger den sidste model, om sammenhængen mellem timers undervisning og timers forberedelse er forskellig alt efter, hvilken uddannelse den studerende gik på. Den statistisk signifikante varians for koefficienten for undervisning $(0,029)$ synes at bekræfte, at effekten af undervisning på forberedelse varierede mellem uddannelser. Den negative kovarians mellem forberedelse og koefficienten for uddannelse $(-0,436)$ kan tolkes på følgende måde: Jo flere timer de studerende på en given uddannelse i gennemsnit forberedte sig om ugen, desto mere negativ var effekten af en yderligere times undervisning.

Efterfølgende analyser viser, at den endelige model er signifikant bedre end nulmodellen, hvor kun forskelle mellem studerende og uddannelser er taget i betragtning, $\chi^{2}(8, N=7.856)=-2^{*}(-29.226,4--28.985,9)=481,0, p<0,001$. Dette betyder, at vi ved at kende antallet af timer brugt på undervisning og erhvervsarbejde samt ved inddragelse af kontrolvariable bedre kan forklare variationer i de studerendes forberedelse. For at vurdere, om vi med modellen har formået at forklare en substantiel del af den store variation i forberedelsestid, betragtes udviklingen i variansen og log likelihoodmålet på tværs af modellerne. Fra model 0 til model 3 reduceres variansen på individniveau med 7\% ([97,7 - 91,3]/97,7). På trods af højere forklaringskraft er der dermed stadig en stor del af variationen i de studerendes forberedelsestid, som modellen ikke kan forklare. 
Figur 2. Udvalgte eksempler på korrelationen mellem undervisning og forberedelse baseret på multilevelmodellen.

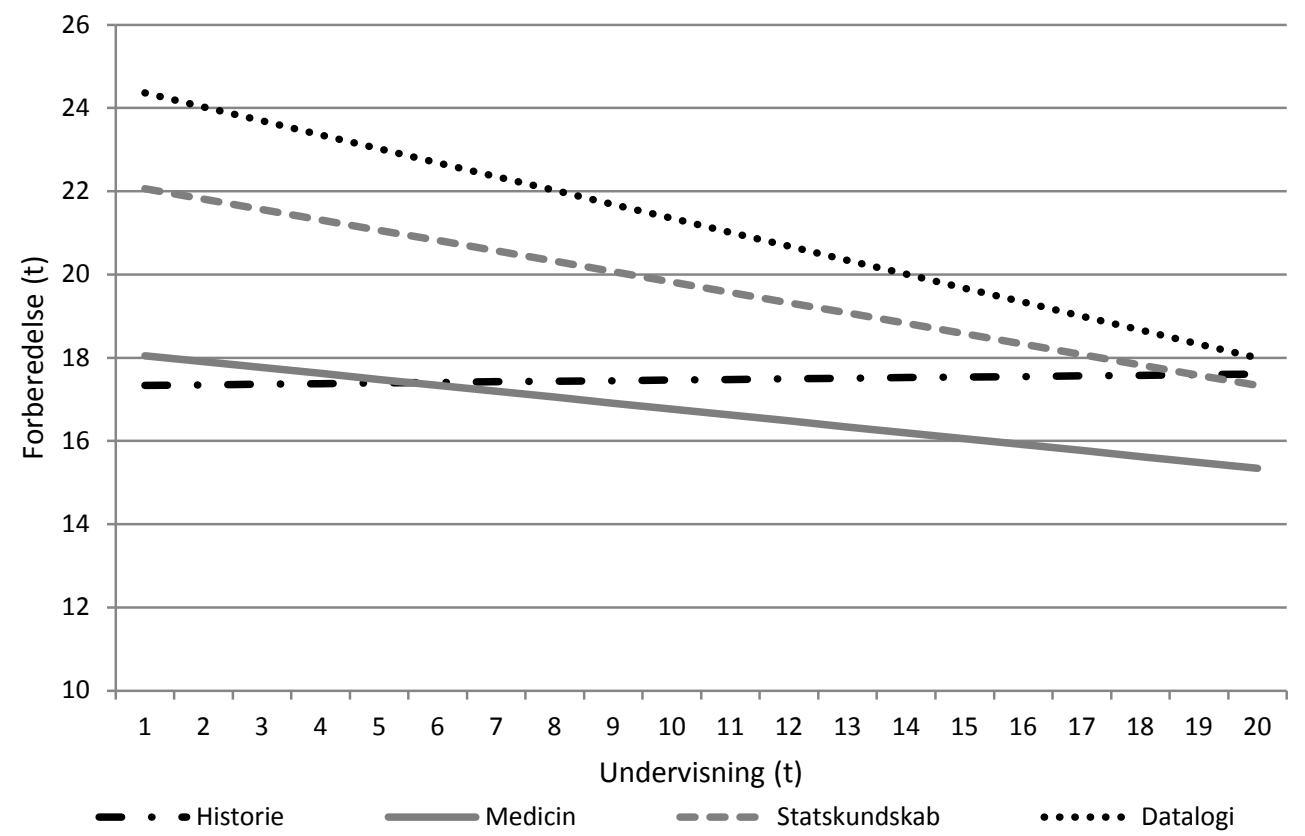

Note: Sammenhængen mellem forberedelsestid og undervisningstid beregnet for en 20-årig mandlig bachelorstuderende uden erhvervsarbejde, som ikke er en del af en læsegruppe.

For at illustrere resultaterne i model 3 har vi medtaget figur 2, som viser sammenhængen mellem timers forberedelse og timers undervisning for studerendes svar inden for fire udvalgte uddannelser. Bemærk, at både hældningskoeffienter og skæringspunkter varierer. Baseret på studerendes svar på uddannelserne medicin, statskundskab og datalogi har linjen en negativ hældning, hvilket indikerer, at der (ifølge den statistiske model) er et fald i den samlede forberedelsestid for hver ekstra undervisningstime. Den stejleste hældning, og dermed den mest negative sammenhæng, har vi fundet blandt de studerende i undersøgelsen som læste datalogi. Gruppen af studerende på uddannelsen historie skiller sig ud ved en (meget svag) positiv hældning.

\section{Opsamling på statistiske resultater}

Den endelige statistiske model kan opsummeres på følgende måde. Vi har fundet en negativ og statistisk signifikant sammenhæng mellem det antal timer, de studerende rapporterede at bruge på at forberede sig, og det antal timer, de studerende rapporterede at bruge på deltagelse i undervisning. For hver time yderligere brugt på undervisning falder tiden brugt på forberedelse i gennemsnit med 0,23 time svarende til 14 minutter. Denne negative effekt viser sig imidlertid at variere alt efter, hvilken uddannelse den studerende befandt sig på. På lignende vis finder vi en negativ og statistisk signifikant sammenhæng mellem timer brugt på erhvervsarbejde og timer brugt på forberedelse. 
Det er ligeledes interessant at bemærke, at kvinderne i undersøgelsen forberedte sig i gennemsnit godt 2 timer mere om ugen end mændene. Kandidatstuderende forberedte sig 1 time mindre end bachelorstuderende, og studerende som igennem semesteret 'ofte' eller 'næsten altid' var medlem af en læsegruppe forberedte sig en time mere om ugen. Endelig forberedte ældre studerende sig mere end yngre studerende.

\section{Diskussion}

\section{En gennemsnitlig studieuge under 37 timer}

For første gang har det været muligt at beregne en gennemsnitlig studieuge for studerende, som ikke alene var indskrevet som fuldtidsstuderende, men som også i det pågældende semester sigtede efter at opnå 30 ECTS. Den gennemsnitlige studieintensitet for de studerende på Aarhus Universitet var 30,3 timer/uge fordelt på henholdsvis undervisning og forberedelse. Tidsmålinger er altid forbundet med usikkerhed, og når man i undersøgelser af studieintensitet finder frem til forskellige resultater kan det meget vel skyldes variationer i operationaliseringen af henholdsvis undervisning og forberedelse, lige som man må forvente forskelle alt efter om man beder studerende tænke tilbage på en konkret uge eller en såkaldt gennemsnitsuge (Rockwoolfonden, 2013). Derfor er det ganske som forventet at man i Eurostudent (2011) og Kvalitetsudvalget (2014a) estimerer en længere studieuge end i AU (2011) og KU (2013). Forskelle i resultater og målingsusikkerhed til trods synes det dog sikkert at konkludere, at den gennemsnitlige danske universitetsstuderende (i lighed med den gennemsnitlige universitetsstuderende i andre europæiske lande [Eurostudent, 2011]) beskæftiger sig mindre end 37 timer/ugen med sine studier, hvilket dermed også er mindre end forudsat ved beregning af ECTS-normen.

Undersøgelsen viser imidlertid også en betydelig spredning i studieintensiteten på tværs af uddannelser, køn og studietrin, hvilket også er i tråd med tidligere danske og internationale undersøgelser. Fx bekræfter denne undersøgelse billedet fra tidligere undersøgelse: At studerende inden for natur- og sundhedsvidenskab som gruppe bruger flere timer på studierne. Vores undersøgelse illustrerer imidlertid også, at der inden for hver gruppe er en meget stor spredning, og denne spredning taget $\mathrm{i}$ betragtning kan man diskutere, om det i det hele taget giver mening at tale om en 'gennemsnitsstuderende'. De studerendes studieintensitet er påvirket af de rammer studiet sætter, og selv inden for den samme ramme (i denne undersøgelse fagområdet og den enkelte uddannelse) kan man observere store forskelle studerende imellem. 


\section{Et negativt forhold mellem undervisning og forberedelse}

Den store spredning i studieintensitet er udgangspunktet for en nærmere analyse af korrelationen mellem tid brugt på undervisning og tid brugt på forberedelse. Analysen viser, at jo flere undervisningstimer de studerende deltog $i$, desto mindre forberedte de sig. Disse analyser er vel at mærke korrigeret for effekten af køn, alder og studietrin ligesom vi ved at anvende multilevelanalyse har taget højde for uddannelseskonteksten. En negativ sammenhæng mellem undervisning og forberedelse er i overensstemmelse med studiet fra DEA (2013) men i modstrid med Kvalitetsudvalgets (2014b) analyser. Man kan spekulere over, om den i gennemsnit negative sammenhæng mellem undervisning og forberedelse er udtryk for en 'crowding-outeffekt', sådan som det forsigtigt blev fortolket i Eurostudent (2011). Med crowdingout menes, at mere undervisning, på trods af intentionen, risikerer at 'fortrænge' noget af den studerendes forberedelse. Data tillader ikke en nærmere analyse af dette, men et nyligt dansk studie af Herrmann (2014) finder, at førsteårsstuderende på statskundskabsstudiet havde meget forskellige opfattelser af, hvad der var rationalet med undervisningen. Nogle studerende anså undervisningen som anledning til at arbejde videre på egen hånd. Andre studerende havde den opfattelse, at hvis bare underviseren gennemgik stoffet grundigt nok, så var de sikret noter til eksamen, hvorfor der ikke var nogen grund til at arbejde videre med stoffet. Hvor undervisning i førstnævnte tilfælde således havde en positiv indvirkning på de studerendes læringsaktiviteter uden for undervisning, havde undervisningen for den anden gruppe af studerende en negativ indvirkning på det selvstændige forberedelsesarbejde, fordi denne gruppe anså god undervisning som en substitut for egen forberedelse. Det kvalitative studie af Herrmann (2014) peger således på noget, vi i dette kvantitative studie ikke har kunnet tage højde for, nemlig de studerendes læringsopfattelse (herunder deres opfattelse af undervisningens funktion).

\section{Analyser på rette niveau}

Både Produktivitetskommissionen (2013), Rigsrevisionen (2011) og UFM (2014) hæfter sig ved Eurostudent (2011) og det øjensynlige resultat, at studieintensiteten stiger med antallet af undervisningstimer. Produktivitetskommissionen (2013:61) skriver, at "undervisningstimer kan bruges som et groft mål for studieintensitet" og at der "formentlig stadig [er] en tæt sammenhæng mellem, hvor meget tid en person bruger på at studere, og hvor meget han eller hun lærer". Denne udlægning af Eurostudent (2011) er imidlertid problematisk. For det første risikerer man at foretage en cirkelslutning ved at sige, at flere undervisningstimer fører til større samlet studieintensitet, da undervisning per definition er indeholdt i studieintensitet. For det andet er det vigtigt at notere, at Eurostudent rapporterer (2011) resultaterne på fagområdeniveau og ikke på individniveau. På dette niveau ser det ganske rigtig ud som om, at studieintensiteten er højere på de akademiske områder (sundhedsvidenskab, naturvidenskab og tekniske 
videnskaber), hvor der er mange undervisningstimer. Problemet er imidlertid, at man ikke kan slutte fra det aggregerede niveau (område) til det individuelle niveau (de studerende), da man herved risikerer at foretage en økologisk fejlslutning (det, der gælder på et højere niveau, gælder ikke nødvendigvis på et lavere). Derfor er det vigtigt, at foretage undersøgelser, som behandler data på individniveau, sådan som det er gjort i DEA (2013) og Kvalitetsudvalget (2014) og nu i denne undersøgelse.

\section{Kvalitet $i$ undervisningen}

Spørgsmålet rejser sig, om et øget udbud af undervisningstimer på universiteterne kan forventes at være effektivt og hensigtsmæssigt ud fra de præmisser, der blev lagt til grund for Produktivitetskommissionens (2013) analyse. Nærværende studie tyder på, at undervisning har en dobbeltrettet effekt på studieintensiteten. Da studieintensiteten er defineret ved antallet af undervisnings- og forberedelsestimer vil studieintensiteten umiddelbart stige, hvis den studerende deltager i mere undervisning. På den anden side ser der ud til at være en modsatrettet, negativ effekt i form af færre forberedelsestimer og dermed mindre studieintensitet (en sådan tolkning er nødvendigvis tentativ, da man med et tværsnitsstudie i princippet ikke kan udtale sig om effekten af en forøgelse i udbuddet af undervisningstimer på en uddannelse). Sagt med andre ord kan man frygte, at undervisning af nogle studerende og i nogle sammenhænge bliver opfattet som en substitut for det selvstændige læringsarbejde mellem undervisningstimer. Dette problem vedrører alene det kvantitative aspekt af studieintensitet, dvs. antal timers studeren. Et andet problem knytter sig til kvaliteten af de studerendes læringsarbejde. En moderne universitetspædagogisk beskrivelse af kvalitet i undervisning vil ikke alene fremhæve omfanget af undervisningen, men også undervisningens tilrettelæggelse såvel som omfanget og kvaliteten af de studerendes forberedelse. Resultaterne fra dette studie tyder på, at omfanget af forberedelsen pr undervisningstime falder, hvilket man kunne frygte tyder på, at kvaliteten af undervisningen falder for hver marginal time med mindre undervisningen målrettet tilrettelægges med de studerendes læringsarbejde før, under og efter undervisningen for øje. Sagt med andre ord: I sig selv er flere timer en hverken nødvendig eller tilstrækkelig forudsætning, hvis målet er at højne og sikre kvaliteten af danske universitetsstuderendes læring.

\section{Begrænsninger og videre studier}

Læseren bør ved tolkning af resultaterne bemærke følgende. For det første, at vi i dette studie bad de studerende rapportere, hvor mange timer, de havde deltaget $i$, hvilket ikke nødvendigvis er det samme som antallet af udbudte timer. Indledende analyser for ekstreme værdier tyder for det andet på, at kategorien undervisning trods en eksplicit definition kan være blevet tolket forskelligt. Fx har det vist sig, at studerende med meget høje timetal var medicinstuderende, som sandsynligvis talte ophold i klinik som undervisning, hvad vi ikke havde forudset i designet af skemaet. 
Den væsentligste begrænsning ved dette studie er imidlertid, at det ikke fremgår af data, hvordan undervisningen var organiseret, og at det er sandsynligt, at netop organiseringen er en afgørende forudsætning for, hvor meget de studerende er motiveret for at forberede sig (Biggs, 2012). Var der tale om undervisning som forudsatte de studerendes forberedelse, eller var der tale om underviserens 'gennemgang' af stoffet uden de studerende deltagelse? Oplevede de studerende, at deres forberedelse var en integreret del af undervisningen, eller oplevede de studerende, at de kunne nøjes med at 'sidde den af'?

Kommende studier kan med fordel tage fat i en nærmere analyse af undervisningens organisering og de studerendes oplevelse af undervisning i relation til omfanget og typen af forberedelse. Her vil casestudier og mere dybdegående kvalitative studier sandsynligvis kunne give et dybere indblik end et stort tværsnitsstudie.

\section{Konklusion og perspektiver}

Analyserne viser, at mange studerende indskrevet på fuldtidsuddannelser havde en studieintensitet, som i praksis lå noget under det antal timer, der ligger til grund for ECTS-normen. Den statistiske model viser yderligere et negativt forhold mellem antallet af besøgte undervisningstimer og antallet af forberedelsestimer, ligesom modellen viser, at sammenhængen mellem undervisning og forberedelse er afhængig af uddannelseskonteksten. Alligevel bør man være forsigtig med herudfra at konkludere, at en investering i mere undervisning nødvendigvis er en dårlig investering, og vi vil heller ikke på baggrund af dette studie fraråde at øge antallet af konfrontationstimer på udvalgte uddannelser. Dette er ikke konklusionen. Konklusionen er, at data fra dette studie ikke støtter en antagelse om, at en forøgelse af antallet af undervisningstimer i sig selv resulterer i forøget studieintensitet. Det er netop dette 'i sig selv', der er det afgørende, fordi de data, der ligger til grund for resultaterne, ikke fortæller noget om undervisningens form eller indhold, ej heller noget om, hvordan underviserne forvalter den undervisningstid, de er givet. Samspillet mellem de studerendes læringsaktiviteter i samvær med en underviser (undervisning) og de studerendes læringsaktiviteter i samvær med andre studerende eller alene (forberedelse) er ganske givet uhyre komplekst, og også så komplekst, at der altid vil være store udfordringer ved at forstå og beskrive sammenhængen kvantitativt. Studiets væsentligste bidrag er 1) at henlede opmærksomheden på den meget store forskel i studerendes individuelle studiepraksis, og 2) at påvise svagheden ved antagelsen om, at flere undervisningstimer i sig selv vil løse problemer med utilstrækkelig studieintensitet. 
Efter vores vurdering bør den vigtigste implikation af de præsenterede resultater være denne: At man i stedet for at fokusere ensidigt på antallet af undervisningstimer begynder at interessere sig for, hvordan undervisningen er organiseret. Hvordan prioriterer danske studerende deres tid, og hvilke forhold i læringsmiljøet motiverer til øget studieintensitet? Hvilke former for undervisning øger de studerendes motivation til at forberede sig? Før disse spørgsmål er besvaret, er det usikkert, om flere konfrontationstimer vil have den ønskede effekt.

Kim Jesper Herrmann er cand.scient.pol., ph.d. og adjunkt ved Center for Undervisning og Laring, Aarhus Universitet. Forsker i universitetsstuderendes studiestrategier og oplevelser af undervisningsmiljøet. Sammen med Anna Bager-Elsborg er han ansvarlig for kompetenceudvikling for studenterundervisere og instruktorer ved School of Business and Social Sciences. Siden 2015 ansvarshavende redaktør for Dansk Universitetspædagogisk Tidsskrift.

Anna Bager-Elsborg er cand.scient.pol. og ph.d.-stipendiat ved Center for Undervisning og Læring, forsker i faglige fællesskabers og faglige diskursers betydning for universitetsunderviseres tilgange til underviserrollen. Har sammen med Kim J. Herrmann været ansvarlig for studiemiljøundersøgelserne ved Aarhus Universitet i 2007, 2011 og 2014. Forfatter til bogen Effektiv holdundervisning - en håndbog for nye undervisere på universitetsniveau ligeledes sammen med Kim J. Herrmann.

Inger Borch Hansen og Rasmus Nielsen, begge stud.scient.pol., er studentermedhjelpere på Center for Undervisning og Lxring og har beskxftiget sig med dataindsamling og analyse af Aarhus Universitets studiemiljøundersøgelse.

\section{Litteratur}

AU, Aarhus Universitet (2011). Rapport nr. 1: Studiemiljø2011 - Aarhus Universitet. Hentet den 17. september fra hjemmesiden: http://www.au.dk/studiemiljo/rapporter/

Baeten, M., Kyndt, E., Struyven, K. \& Dochy, F. (2010). Using student-centred learning environments to stimulate deep approaches to learning: Factors encouraging or discouraging their effectiveness. Educational Research Review, 5, s. $243-260$.

Biggs, J. (2012). What the Student Does: Teaching for Enhanced Learning. Higher Education Research and Development, 31, s. 39-55.

DEA, Danmarks ErhvervsforskningsAkademi (2013). Motivation og studieintensitet hos universitetsstuderende: En spørgeskemaundersøgelse i Danmark, Sverige, Tyskland og England. Hentet den 17. september fra hjemmesiden: http://dea.nu/sites/dea.nu/files/Motivation\%200g\%20studieintensitet WEB.pdf

Entwistle, N. (2009). Teaching for Understanding at University: Deep Approaches and Distinctive Ways of Thinking. Basingstoke: Palgrave Macmillan.

Eurostudent (2011). Social and Economic Conditions of Student Life in Europe: Synopsis of indicators. Bielefeld: W. Bertelsmann Verlag. Tilgængelig på: http://www.eurostudent.eu/download files/documents/EIV Synopsis of Indic ators.pdf

Hattie, J. (2009). Visible Learning: A Synthesis of Over 800 Meta-Analysis Relating to Learning. New York: Routledge. 
Herrmann, K. (2014). Learning from tutorials: a qualitative study of approaches to learning and perceptions of tutorial interaction. Higher Education, 68(4), s. 591606.

Hox, J. (2010). Multilevel Analysis: Techniques and Applications (2. udg.). New York: Routledge.

KU, Københavns Universitet \& Rambøll (2013). Tilfredshed studerende 2013: Universitetsrapport. Rapporten er ikke offentligt tilgængelig men kan tilgås via Københavns Universitets intranet.

Kvalitetsudvalget, Udvalg for Kvalitet og Relevans i de Videregående Uddannelser (2014a). Høje mål - fremragende undervisning $i$ videregående uddannelser. Analyserapport. Hentet den 16. december fra hjemmesiden: www.ufm.dk/kvalitetsudvalget.

Kvalitetsudvalget, Udvalg for Kvalitet og Relevans i de Videregående Uddannelser (2014b). Spørgeskemaundersøgelse blandt studerende og undervisere på de videregående uddannelser - Resultatbilag. Hentet den 16. december fra hjemmesiden: www.ufm.dk/kvalitetsudvalget.

Produktivitetskommissionen (2013). Uddannelse og Innovation. Analyserapport 4. Hentet den 17. september 2014 fra hjemmesiden: http://produktivitetskommissionen.dk/media/162592/Analyserapport $\% 204, \% 20$ Uddannelse $\% 200 \mathrm{o} \% 20$ innovation revideret.pdf

Rabe-Hesketh, S. \& Skrondal, A. (2008). Multilevel and Longitudinal Modeling Using Stata (2. udg). College Station, TX: STATA Press.

Rienecker, L., Jørgensen, P., Dolin, J. \& Ingerslev, G. (red.). (2013). Universitetspædagogik. Frederiksberg: Samfundslitteratur.

Rigsrevisionen (2012). Beretning til Statsrevisorerne om undervisningen på universiteterne. Hentet den 17. september fra hjemmesiden: http://www.rigsrevisionen.dk/media/1815984/16-2011.pdf

Rockwool Fondens Forskningsenhed (2012). Nyhedsbrev juni 2012. Hentet den 17. september 2014 fra hjemmesiden: http://www.rff.dk/files/RFFsite/Publikations\%20upload/Newsletters/Dansk/Nyhedsbrev\%20Juni\%202012. pdf

Tabachnick, B. \& Fidell, L. (2007). Using Multivariate Statistics (5. udg.). New York: Pearson Education.

Trowler, V. (2010). Student engagement literature review, Department of Educational Research, Lancaster University. Hentet den 16. december 2010 fra hjemmesiden:

https://www.heacademy.ac.uk/sites/default/files/StudentEngagementLiterature Review 1.pdf

UFM, Uddannelses- og forskningsministeriet (2014). Udviklingskontrakter for de videregående uddannelsesinstitutioner $i$ perioden 2015-2017. Hentet den 16. september på ministeriets hjemmeside: http://ufm.dk/uddannelse-oginstitutioner/videregaende-uddannelse/filer/styring-ogansvar/udviklingskontrakter/brev-om-udviklingskontrakter-2015-2017.pdf

Ulriksen, L. (2014). God undervisning på de videregående uddannelser: En forskningsbaseret brugsbog. Frederiksberg: Frydenlund 